\title{
PERANAN LINGKUNGAN BAHASA TERHADAP UNGKAPAN KEGEMBIRAAN ANAK USIA DUA TAHUN (STUDI KASUS ARKHAN)
}

\author{
Era Makatita Puspa Harum Sari
}

Fakultas Ilmu Tarbiyah dan Keguruan, UIN Syarif Hidayatullah Jakarta, Jl. Ir. H. Juanda No. 95, Cempaka Putih, Ciputat Timur, Tangerang Selatan, Banten, era.makatita@gmail.com

\begin{abstract}
When a child reach the age of two years, he tends to actively produce words. The activity of producing these words was the result of acquiring the first language which he had unconsciously done since he was born into the world. Language functions as a means of communication between humans. the process of acquiring children's language must not be separated from the role of the language environment that surrounds it. The language environment also affects the expression of children's emotions through the language they have acquired. One of the least studied forms of emotion is the expression of joy. Based on this, this study aims to find the role of the language environment in the expression of joy of two year olds child. This study used a qualitative descriptive method with observation and interview techniques. The results of the study show that the role of the language environment in the expression of children's joy is through the family environment and electronic media by observing, imitating, and trial-error.
\end{abstract}

Keywords: psycholinguistics, language environment, expressions of joy

\begin{abstract}
ABSTRAK
Memasuki usia dua tahun anak cenderung aktif memproduksi kata. Aktivitas memproduksi kata tersebut merupakan hasil dari pemerolehan bahasa pertama yang tanpa ia sadari telah dilakukannya sejak lahir ke dunia. Bahasa berfungsi sebagai alat komunikasi antar manusia. proses pemerolehan bahasa anak pasti tidak terlepas dengan peran lingkungan bahasa yang melingkupinya. Lingkungan bahasa pula yang memengaruhi pengungkapan emosi anak lewat bahasa yang telah ia peroleh. Salah satu bentuk emosi yang paling jarang diteliti adalah ungkapan kegembiraan. Berdasarkan hal tersebut penelitian ini bertujuan mencari peranan lingkungan bahasa terhadap ungkapan kegembiraan anak usia dua tahun. Penelitian ini menggunakan metode deskriptif kualitatif dengan teknik observasi dan wawancara. Hasil dari penelitian yakni diketahui bahwa peran lingkungan bahasa terhadap ungkapan kegembiraan anak adalah melalui lingkungan keluarga dan media elektronik dengan cara anak mengamati, meniru, membiasakan diri, dan trial-error.
\end{abstract}

Kata Kunci: psikolinguistik, lingkungan bahasa, ungkapan kegembiraan

How to Cite: Era Makatita Puspa Harum Sari. (2021). PERANAN LINGKUNGAN BAHASA TERHADAP UNGKAPAN KEGEMBIRAAN ANAK USIA DUA TAHUN (STUDI KASUS ARKHAN). Bahtera Indonesia; Jurnal Penelitian Bahasa Dan Sastra Indonesia , 6(2), 236-249. https://doi.org/10.31943/bi.v6i2.100

DOI: https://doi.org/10.31943/bi.v6i2.100 


\section{PENDAHULUAN}

Perjalanan hidup seseorang akan dimulai sejak ia dilahirkan. Perkembangannya kemudian akan bergerak dari masa anak-anak, remaja, dewasa, hingga tua. Masa anak-anak adalah masa pembentukan diri yang amat penting untuk diperhatikan. Mulai dari aspek fisik, psikologis, kognitif, hingga aspek bahasa. Bagaimana seorang anak dapat berbahasa dalam waktu yang cenderung singkat tentunya menjadi hal yang menarik untuk dibahas secara ilmiah.

Berbahasa merupakan proses manusia saling memahami menggunakan isyarat komunikasi yang dinamai bahasa. Bagaimana seseorang dapat berbahasa sangat bergantung terhadap proses pemerolehan dan pembelajaran bahasa. Berbicara tentang pemerolehan bahasa, kemampuan seorang anak memproduksi bahasa dapat dikatakan berpatokan pada bagaimana ia memperoleh bahasa tersebut. Bagi sang anak bahasa adalah sarana pengungkapan pikiran, keinginan, ketidaksetujuan, dan hal lain yang berguna sebagai bentuk aktualisasi diri.

Sejak bayi sebenarnya kita telah mengalami proses pemerolehan bahasa lewat interaksi terhadap lingkungan sekitar. Sejak awal orang tua akan mencoba melakukan komunikasi dengan anaknya seolah-olah anak tersebut dapat mengerti dan memberi respon.
Dengan begitulah seorang anak akan mulai memperoleh bahasa yang akan digunakannya untuk berkomunikasi. Menurut Gleason (Nuryani \& Putra, 2013: 88) pemerolehan bahasa merupakan salah satu pokok bahasan utama psikolinguistik yang berisi prosedur bagaimana seorang anak dapat memahami dan memproduksi bahasa pertamanya.

Sebelumnya telah disebutkan bahwa bahasa adalah alat aktualisasi diri seseorang. Bahasa dapat digunakan untuk mengaktualisasi pikiran, keinginan, pendapat, bahkan emosi seseorang. Sejak lahir seorang anak dibekali dengan perangkat perasaan yang dapat merasakan emosi. Emosi yang dirasakan manusia secara alami akan melakukan perubahan terhadap fisiologi, detak jantung, tekanan darah, pernapasan, dan lain sebagainya. Perubahan-perubahan tersebut pada akhirnya menimbulkan reaksi yang nampak lewat gestur, raut wajah, suara, atau diungkapkan secara langsung lewat bahasa. Hurlock (Riana, 2015: 30) menyebutkan macam-macam emosi yang umum dirasakan oleh anak-anak yaitu ketakutan, kemarahan, kecemburuan, dukacita, keingintahuan, kegembiraan, dan kasih sayang.

Saat berkomunikasi dengan seseorang, kita tidak dapat memungkiri bahwa dalam memahami maksud ujaran perlu memperhatikan perilaku nonverbal lawan 
tutur. Perilaku nonverbal merupakan reaksi dari gejolak emosi yang dirasakan seseorang. Abai terhadap aspek nonverbal dapat membuka lebar peluang salah tafsir. Pada kenyataannya kita tidak dapat menafsirkan ujaran secara pasti dengan hanya melihat kepada bahasanya saja. Aspek nonverbal yang dapat kita amati dari lawan tutur antara lain adalah pengungkapan emosi. Pengungkapan emosi ini tentu berbeda sesuai pengalaman interaksi lawan tutur dengan lingkungannya.

Lingkungan memiliki pengaruh yang besar terhadap pemerolehan bahasa. Bila berdasar pada teori behavioristik, seorang anak akan sangat bergantung pada interaksinya dengan lingkungan dalam proses pemerolehan bahasa. Selain berpengaruh pada proses pemerolehan bahasa, lingkungan juga memiliki pengaruh yang cukup kuat terhadap perkembangan emosi anak. Thompson dan Lagatutta (Riana, 2015: 20) berpendapat bahwa perkembangan emosi anak mendapatkan pengaruh dari pengalamannya dengan lingkungan sekitar. Apa yang dipelajari anak sehari-hari akan membentuk pola tanggapan emosi. Oleh sebab itu, masing-masing anak akan memiliki pola tanggapan emosi yang berbeda tergantung pengalaman interaksinya dengan lingkungan sekitar.
Usia dua tahun merupakan fase di mana seorang anak telah mampu berkomunikasi menggunakan kata yang bermakna. Saat anak berusia dua tahun ke atas, mereka akan mulai dapat memproduksi kalimat dengan dasar gramatikal utama subjek dan objek. Hal ini disebabkan penguasaan aspek linguistiknya telah memasuki pemerolehan sintaksis yang membuat produksi kata yang mereka lakukan semakin aktif dan berkembang, baik secara kuantitatif maupun kualitatif.

Penulis melihat ranah afektif belum banyak diambil untuk diteliti. Emosi merupakan bagian dari ranah afektif. Sejauh observasi penulis emosi gembira sangat sedikit diteliti dibandingkan dengan emosi marah dan rasa takut. Sebuah penelitian yang dilakukan Etin Pujihastuti dkk mengenai "Pengungkapan Kegembiraan Pada Anak Usia 3-5 Tahun dalam Kajian Psikolinguistik" menemukan bahwa anak usia 3-5 tahun mengungkapkan kegembiraan lewat ujaran yang dapat diteliti dari tataran fonologi, morfologi, dan sintaksis. Penelitian tersebut hanya berfokus pada pengungkapan kegembiraan anak dalam tataran bahasa. Penulis menemukan belum ada pembahasan mengenai peranan lingkungan bahasa terhadap pengungkapan kegembiraan anak, padahal lingkungan bahasa sangat berpengaruh terhadap pengembangan emosi 
juga pemerolehan bahasa. Oleh karena itu, melalui penelitian ini penulis berharap dapat mendeskripsikan peranan lingkungan bahasa terhadap ungkapan kegembiraan anak usia dua tahun (studi kasus Arkhan).

Berdasarkan penjelasan tersebut, masalah dapat dirumuskan sebagai berikut. Bagaimana peranan lingkungan bahasa terhadap ungkapan kegembiraan anak usia dua tahun?

\section{KAJIAN TEORI}

\section{Pemerolehan Bahasa}

Sejak lahir seorang anak sudah melakukan aktivitas komunikasi dengan orang lain, khususnya sang ibu. Banyak penelitian bahkan telah membuktikan bahwa proses komunikasi manusia sudah dapat dilakukan sejak dalam kandungan. Salah satu alat komunikasi manusia adalah bahasa. Bayi yang belum dapat berbahasa melakukan komunikasi lewat reaksi yang mengandung makna dan memerlukan tanggapan. Proses seorang anak mengenal dan memproduksi bahasa merupakan bahasan pemerolehan bahasa.

Menurut Abdul Chaer (2009: 167) pemerolehan bahasa atau dalam padanan Inggris disebut language acquisition adalah proses yang berlangsung di dalam otak seorang anak ketika dia memperoleh bahasa pertama atau bahasa ibunya. Krashen
(Nuryani \& Putra, 2013: 89) mengartikan pemerolehan bahasa sebagai "The product of a subconscious process very similar to the process children undergo when they acquire their first language". Berdasarkan penjelasan Krashen tersebut dapat diartikan bahwa pemerolehan bahasa adalah proses atau cara seseorang dapat memperoleh bahasa pertamanya. Proses pemerolehan bahasa dapat dikatakan sebagai aktivitas tak sadar. Seseorang umumnya tidak sadar bahwa ia sedang memperoleh bahasa dan hanya sadar saat menggunakan bahasa tersebut untuk berkomunikasi. Dengan demikian, dapat disimpulkan bahwa pemerolehan bahasa adalah proses pemerolehan (penguasaan) bahasa pertama seorang anak secara naluriah (alami), tidak sadar, dan tidak bermaksud memahami kaidah bahasa pertama untuk berkomunikasi.

Ada beberapa teori yang berkaitan dengan pemerolehan bahasa yakni teori behavioristik, teori mentalistik, teori kognitif, dan teori interaksionisme.

\section{Teori behavioristik}

Kaum behavioristik beranggapan bahwa sejak lahir anak tidak membawa struktur linguistik atau potensi bahasa. Teori behavioristik selaras dengan hipotesis tabularasa yang didasari oleh John Locke bahwa anak yang baru lahir merupakan kertas kosong yang nantinya akan diisi oleh 
pengalaman-pengalaman yang dialaminya. Pengalaman dan proses belajarlah yang mendasari pemerolehan bahasa.

Menurut Skinner (Nuryani \& Putra, 2013: 102) tingkah laku bahasa dilakukan dengan cara penguatan, yakni melalui proses stimulus dan respon. Kaum behavioris menggunakan pola tingkah laku bahasa untuk menghasilkan respon yang benar terhadap stimulus. Jika respon terhadap stimulus tidak ditolak, maka hal tersebut akan menjadi kebiasaan. Berdasarkan teori ini dipahami bahwa anak-anak memperoleh bahasa melalui hubungan dengan lingkungan, tepatnya dengan cara meniru. Hal penting yang dilihat dari peniruan adalah frekuensi berulangnya suatu kata.

\section{Teori mentalistik}

Teori mentalistik sejalan dengan pendapat Chomsky (Nuryani \& Putra, 2013: 104) yang menerangkan bahwa sejak lahir seorang anak telah membawa potensi bahasa yang akan berkembang seiring bertambahnya usia. Perangkat bahasa bawaan ini dikenal dengan Language Acquisition Device (LAD). Chomsky mengatakan bahwa LAD merupakan suatu bagian dari otak yang dikhususkan untuk memproses bahasa.

Penganut aliran ini berpendapat bahwa bahasa adalah suatu hal yang kompleks dan rumit sehingga tidak mungkin dikuasai dalam kurun waktu singkat. Perangkat LAD mewadahi anak dalam proses pemerolehan bahasa, sedangkan bahasa yang diperoleh bergantung pada bahasa yang digunakan oleh masyarakat sekitar (Thoriqussu'ud, 2013: 103). Dengan demikian, secara alami anak dibekali dengan kemampuan berbahasa. Perkembangan bahasa tidak dilakukan sedikit demi sedikit pada struktur bahasa yang tidak benar dan standia lanjut, tetapi sistem yang membentuk kelengkapan-kelengkapan bawaan ditambah dengan pengalaman anak dalam bersosialisasi.

\section{Teori kognitif}

Teori yang dibuat oleh Piaget ini menjelaskan bahwa pemerolehan bahasa bukan satu hal yang terpisah, tetapi merupakan bagian dari perkembangan kematangan kognitif yang distrukturi nalar. Dengan kata lain urutan perkembangan bahasa akan sesuai dengan urutan perkembangan kognisi (Thoriqussu'ud, 2013: 105).

Piaget (Nuryani \& Putra, 2013: 99) menjelaskan bahwa struktur kompleks bahasa bukanlah sesuatu yang didapatkan dengan cara alami dan bukan pula sesuatu yang terhasil dari interaksi dengan lingkungan secara berkesinambungan. Struktur ini diciptakan dari interaksi kognisi anak dengan lingkungan bahasa dan nonbahasa.

4. Teori interaksionisme 
Teori interaksionisme berpendapat bahwa pemerolehan bahasa tercipta dari interaksi kemampuan mental anak dengan lingkungan bahasa. Teori ini sebenarnya merupakan kombinasi dari teori behavioristik dan teori mentalistik. Teori ini mengakui bahwa sejak lahir seorang anak telah memiliki perangkat bahasa bawaan atau LAD yang mendasari kemampuan bahasanya. Namun, tanpa adanya masukan yang sesuai maka LAD tersebut tidak akan berkembang. Menurut teori ini faktor internal dan eksternal sama-sama bersinergi dalam proses pemerolehan bahasa anak. Singkatnya adalah kecerdasan bawaan dan lingkungan merupakan faktor penting dalam pemerolehan bahasa yang saling mendukung satu sama lain (Thoriqussu'ud, 2013: 106).

Ingram (Nuryani \& Putra, 2013: 91) berpendapat bahwa secara tradisional pemerolehan bahasa terbagi menjadi empat tahap.

1. Tahap pralinguistik ( $0-12$ bulan)

Tahap ini seorang bayi hanya dapat mengeluarkan suara atau bunyi. Bunyi-bunyi yang berupa vokal dan konsonan tersebut tidak mengacu pada makna tertentu. Pada tahap ini tangisan berperan penting dalam proses komunikasi bayi. Anak mulai memperoleh bahasa ketika berusia kurang dari satu tahun. Sebagian anak sudah dapat mengucapkan satu suku kata yang berulang, seperti mamamama.

2. Tahap satu kata (12-18 bulan)

Pada tahap ini anak telah mampu mengeluarkan satu kata yang merupakan gambaran dari keseluruhan ide yang dimaksudnya. Kata yang umumnya diucapkan berupa objek atau perbuatan tertentu yang merujuk pada hal di dunia nyata. Konsonan bilabial /b/,/p/, /m/ umumnya lebih dulu dikuasai oleh anak sebab mudah diucapkan.

3. Tahap dua kata (18-24 bulan)

Umumnya pada masa ini anak sudah mampu mengombinasikan dua kata dalam ucapan pendek tanpa kata petunjuk, kata depan, atau bentuk lain yang sesuai kaidah kebahasaan. Pada tahap ini anak mulai memahami makna kata, namun belum bisa menyebutkan jumlah, jenis kelamin, atau waktu.

4. Tahap banyak kata ( $3-5$ tahun)

Pada usia ini anak telah memiliki perbendaharaan kata yang cukup kaya sehingga mampu mengombinasikan tiga kata atau lebih. Anak juga telah mampu membuat kalimat-kalimat sederhana degan pola gramatika yang mulai bervariasi. Selain itu, anak juga telah mampu menggunakan bahasa untuk kegiatan emotif yang lebih kompleks, misalnya bercanda atau merajuk.

Secara khusus Ingram dan Stern (Nuryani \& Putra, 2013: 94) juga membuat 
klasifikasi tahap pemerolehan bahasa ke dalam lima tahap yang lebih signifikan. Pertama, tahap pendahuluan (tahun pertama).

Tahap ini dicirikan dengan mengoceh, meniru, dan pemahaman awal. Kedua, periode pertama ( $1-1,5$ tahun). Pada tahap ini anak mulai mengeluarkan sejumlah bunyi atau satu kata yang menggambarkan keseluruhan ide, namun belum memahami tata bahasa. Ketiga, periode kedua $(1,5-2$ tahun). Pada usia ini anak telah menyadari bahwa semua kata memiliki makna sehingga pertambahan kosakata berupa nomina dan verba juga signifikan. Keempat, periode ketiga (2-2,5 tahun). Tahap ini anak mulai membentuk kalimat dengan baik menggunakan relasi gramatikal utama seperti subjek dan objek. Kelima, periode keempat (2,5 tahun ke atas). Pada periode ini anak terus memperoleh morfem gramatikal dan mulai merambah masalah waktu dan kausalitas.

Berdasarkan tataran kebahasaan, Zuchdi dan Budiasih (Nuryani \& Putra, 2013: 107) membagi pemerolehan bahasa ke dalam tiga tahap. Pertama, tahap fonologis $(0-2$ tahun), pada usia ini anak mulai memproduksi kata-kata sederhana dan bunyi-bunyi bahasa. Kedua, tahap sintaksis (2-7 tahun), anak mulai dapat memproduksi ujaran berupa kalimat dan menyadari sistem gramatikal bahasa. Ketiga, tahap semantik (7-10 tahun), pada tahap ini anak sudah dapat mengaitkan kata sebagai simbol dan konsep.

Berdasarkan beberapa pembagian tersebut dapat disimpulkan bahwa anak usia 2 tahun ke atas dalam tataran kebahasan sudah masuk pada pemerolehan sintaksis sehingga dapat memproduksi kalimat dan menggunakannya dengan membangun relasi gramatikal utama seperti subjek dan objek. Perbendaharaan kosakata sudah meliputi nomina, verba, dan preposisi dasar.

\section{Emosi Gembira Anak}

Secara lahiriah manusia dianugerahi komponen perasaan yang terstruktur guna merespon suatu peristiwa. Anugerah tersebut biasa kita kenal dengan emosi. Secara bahasa emosi berasal dari bahasa Latin yakni movere yang bermakna menggerakan atau bergerak, dan dorongan untuk bertindak. Menurut Lewis dan Haviland-Jones (Riana, 2015: 16) emosi dapat diartikan sebagai aktivitas fisik eksternal, atau reaksi menyenangkan atau tidak menyenangkan terhadap peristiwa atau kondisi mental tertentu. Emosi berhubungan dengan kondisi mental yang memengaruhi aktivitas fisik manusia sebab menciptakan perubahan fisiologi dalam hal pernapasan, detak jantung, dan perubahan kelenjar. Perkembangan emosi anak akan sangat dipengaruhi oleh lingkungan terdekat, khususnya ibu. 
La Freniere (Riana, 2015: 30) membagi emosi dasar pada anak ke dalam dua bentuk, yakni emosi positif dan negatif. Emosi positif meliputi kegembiraan dan kekaguman atau minat, sedangkan emosi negatif meliputi marah, takut, sedih, dan jijik.

Emosi gembira pada seseorang dapat terlihat dari beberapa tanda. Pertama, detak jantung dan tekanan darah menurun sebab oksigen yang dialirkan ke otak dan otot tidak berlebih. Kedua, ritme pernapasan saat gembira cenderung panjang dan lepas. Ketiga, saat gembira seseorang akan cenderung lebih rileks sehingga pembuluh darah melentur dan wajah berseri. Keempat, rileks yang dirasakan saat gembira juga memengaruhi pancaindra sehingga membuatnya kurang sensitif. Kelima, saat gembira zat kimiawi darah tidak akan berubah sebab tidak ada adrenalin dan kortisol yang dilepaskan ke dalam darah.

Emosi kegembiraan pada anak usia 2 tahun biasanya berupa seruan-seruan singkat disertai kegiatan melompat, tertawa, bersenandung, dan reaksi spontan lainnya. Kegembiraan anak dipengaruhi oleh tiga hal yakni penerimaan, kasih sayang, dan prestasi. Penerimaan berarti penerimaan oleh orang lain dan diri sendiri. Seorang anak akan melakukan penyesuaian emosi dan bahasa dengan baik bila ia merasa diterima di lingkungan tersebut. Penerimaan akan berbanding lurus dengan harapan kasih sayang. Semakin anak diterima orang lain, maka semakin besar perasaan kasih sayang yang akan mereka rasakan. Bentuk penerimaan dan kasih sayang dapat dirasakan anak lewat perhatian, pemenuhan keinginan, hadiah, dan lain sebagainya. Kegembiraan lainnya juga dapat dirasakan anak karena prestasi. Keberhasilan melakukan sesuatu akan terasa penting bagi anak usia 2 tahun sebab pada fase itulah anak sudah mulai mampu melakukan beberapa aktivitas secara mandiri. Prestasi yang diakui oleh anggota kelompok akan memberikan perasaan gembira pada anak sekaligus mendorongnya melakukan hal serupa secara terus menerus sebab dianggap benar. Pengakuan prestasi dapat berbentuk pujian atau persetujuan terhadap aktivitas yang dilakukan anak (Riana, 2015: 31).

\section{Lingkungan Bahasa}

Kemampuan berbahasa seorang anak akan berkembang seiring pengalamannya berinteraksi dengan lingkungan sekitar. Pengalaman yang dialami anak tentunya berhubungan dengan pengondisian lingkungan terhadap tingkah lakunya. Lingkungan merupakan hal penting dalam proses perkembangan anak. Selain sangat berpengaruh dalam pemerolehan bahasa, lingkungan juga memegang peran dalam proses produksi atau komunikasi anak. 
Lingkungan adalah segala hal yang ada di sekitar manusia. Lingkungan melibatkan seluruh pancaindra terutama penglihatan dan pendengaran (Utomo et al., 2009: 1). Berlandaskan hal tersebut maka dapat dipahami bahwa lingkungan bahasa adalah suatu wilayah tempat suatu bahasa tumbuh, berkembang, dan digunakan meliputi hal-hal yang dapat didengar dan dilihat sehingga memengaruhi proses berbahasa. Lingkungan bahasa merupakan salah satu faktor yang memungkinkan seorang anak memperoleh suatu bahasa. Kualitas lingkungan bahasa akan memengaruhi keberhasilan pemerolehan bahasa.

Krashen (1981: 40) membagi lingkungan bahasa menjadi dua macam, yaitu lingkungan artifisial atau lingkungan formal dan lingkungan natural atau lingkungan informal.

\section{Lingkungan formal}

Lingkungan formal adalah lingkungan resmi yang dibuat secara terstruktur dan terencana. Krashen (Purba, 2013: 17) menyebutkan beberapa ciri lingkungan formal: (1) bersifat artifisial, (2) pada lingkungan tersebut pembelajar diarahkan untuk berbahasa dengan kaidah dan aturan yang telah dipelajari dan guru memberikan tanggapan sebagai koreksi atas kekeliruan, dan (3) anggota dari keseluruhan pembelajaran di kelas.
Melihat dari ciri tersebut tampaknya dapat dijelaskan kembali bahwa lingkungan formal melibatkan aspek sadar. Maksudnya adalah bahwa anak secara sadar diarahkan untuk menguasai sistem-sistem bahasa dan menggunakannya dalam komunikasi. Anak memperoleh bahasa secara sadar dan mendapatkan bimbingan dari guru. Dengan demikian, dapat disimpulkan bahwa lingkungan formal lebih cenderung berhubungan dengan proses pembelajaran bahasa.

2. Lingkungan informal

Lingkungan informal adalah lingkungan yang secara alami ada tanpa terencana sebelumnya. Lingkungan informal memiliki cakupan yang lebih luas dari lingkungan formal karena sifatnya yang fleksibel dan tidak terencana. Lingkungan informal bisa meliputi apapun, seperti komunikasi dengan keluarga, komunikasi di pasar, dan tempat lainnya yang terjadi secara alami (Purba, 2013: 18). Berdasarkan hal tersebut dapat disimpulkan bahwa lingkungan informal lebih berperan dalam proses pemerolehan bahasa dibandingkan lingkungan formal.

\section{METODE PENELITIAN}

Metode yang digunakan dalam penelitian ini adalah metode deskriptif kualitatif. Melalui metode ini penulis akan mengumpulkan data untuk kemudian 
dianalisis dan diberikan interpretasi sesuai kebutuhan. Hal yang mendasari penulis menggunakan metode deskriptif kualitatif adalah metode ini membuat penulis dapat menganalisis data berdasarkan apa yang benar-benar tertera di dalam data sehingga dapat memungkinkan analisis tiap temuan dilakukan secara mendalam. Teknik yang digunakan dalam pengumpulan data adalah teknik observasi dan wawancara.

Subjek penelitian adalah seorang anak laki-laki berusia 2 tahun 6 bulan bernama Muhamad Arkhan Zayyan Ramadhan atau biasa disapa Arkhan. Objek penelitian adalah ungkapan kegembiraan Arkhan yang ditunjukkan lewat interaksi dengan beberapa orang terdekatnya.

Penyusunan data hingga mendapatkan hasil dilakukan melalui beberapa tahap. Pertama, penulis mengamati objek penelitian selama kurang lebih dua minggu. Kedua, data yang berupa kejadian dan ujaran penulis catat pada sebuah buku. Ketiga, data yang ada dianalisis berdasarkan teori yang telah dipilih penulis dalam acuan teori. Keempat, melakukan pembahasan sesuai kebutuhan.

\section{HASIL DAN PEMBAHASAN}

Ingram dan Stern membagi pemerolehan bahasa kedalam lima tahap: (1) tahap pendahuluan usia $0-1$ tahun, (2) periode pertama usia $1-1,5$ tahun, (3) periode kedua usia 1,5-2 tahun, (4) periode ketiga usia 2-2,5 tahun, (5) periode keempat usia 2,5 tahun ke atas. Subjek penelitian yang diambil penulis adalah seorang anak laki-laki berusia 2,5 tahun yang berarti telah masuk ke dalam periode ketiga. Saat usia 2,5 tahun, seorang anak telah mampu membuat kalimatkalimat sederhana dengan menggunakan relasi gramatikal utama subjek dan objek. Tataran bahasa sudah sampai ke tahap pemerolehan sintaksis. Akan tetapi, anak belum sepenuhnya memahami makna kata. Anak hanya tahu penggunaan kata tersebut sebab meniru. Saat mendapat respon yang diinginkan dan tidak mendapat kritik, anak mulai mengulang kata untuk kebutuhan tertentu.

Sebelumnya telah dijelaskan bahwa lingkungan informal memiliki peran besar dalam proses pemerolehan bahasa anak. Lingkungan informal memiliki cakupan yang luas sebab bersifat alami dan tidak terstruktur. Oleh sebab itu penulis akan membatasi lingkungan informal yang memiliki peran dominan dalam pemerolehan bahasa anak usia 2,5 tahun, yakni keluarga dan media elektronik.

\section{Keluarga}

Keluarga merupakan anggota terdekat anak sejak lahir, terutama ibu. Frekuensi interaksi dengan anggota keluarga akan berefek pada cara anak berkomunikasi. 
(1) Konteks: Pada suatu sore tiba-tiba Arkhan (B) diberi topi oleh mamanya (A).

A: Arkhan lihat mama punya apa! (sambil menunjukkan sebuah topi)

B: Topi.

A: Iya, topi buat Arkhan.

B: Hehehe. (sambil tersenyum dan memeluk mamanya)

Ungkapan kegembiraan pada data (1) ditampilkan lewat tataran fonologi berupa bunyi hehehe. Bunyi yang merupakan rangkaian fonem tersebut diujarkan si anak sebagai gambaran emosinya saat menerima topi baru dari mamanya. Agaknya sejak kecil kita akan secara naluriah tertawa saat merasa bahagia. Selain karena reflek alami, ungkapan hehehe sebagai bentuk kegembiraan biasa dilakukan oleh orang dewasa, begitu pula oleh anggota keluarga Arkhan. Sebab sejak kecil melihat bahwa ungkapan tersebut digunakan saat bahagia maka si anak juga menggunakannya untuk mengungkapkan emosi gembira saat menerima topi baru.

(2) Konteks: Pada suatu malam Arkhan (B) sedang bermain dengan neneknya (A) lalu tiba-tiba sang ayah, yang sebelumnya berjanji akan membelikan robot kesukaannya, pulang.

A: Arkhan bapak pulang, tuh. (sambil menunjuk sang bapak di depan pintu)
B: Bapak pulang, hore! Bawa robot iron man, hore! (melompat-lompat menghampiri bapaknya)

Data (2) menunjukkan ungkapan kegembiraan anak dalam tataran sintaksis berupa kalimat. Arkhan yang sebelumnya telah dijanjikan akan dibelikan robot saat ayahnya pulang menyambut gembira kembalinya sang ayah. Ungkapan Bapak pulang, hore! Bawa robot iron man, hore! menunjukkan kalimat dengan struktur gramatikal yang baik. Hal ini terjadi sebab ungkapan tersebut merupakan hasil peniruan dari ungkapan yang sering diujarkan sang mama saat menyambut bapak pulang. Melalui penglihatan bahwa ungkapan tersebut digunakan disertai dengan nada ceria dan wajah yang bahagia maka si anak menyimpannya sebagai ungkapan bahagia dan menggunakannya saat merasa gembira sebab kepulangan sang ayah.

(3) Konteks: Suatu hari di dalam kamar Arkhan (B) sedang bermain lego ditemani mamanya (A).

B: Mama, Mamas Arkhan buat jerapah. (sambil tersenyum bahagia)

A: Wah, hebat! (sambil bertepuk tangan)

Data (3) menunjukkan ungkapan kegembiraan dengan cara yang berbeda dengan data sebelumnya. Pada data (3) ungkapan kegembiraan ditunjukkan melalui 
ujaran Mama, Mamas Arkhan buat jerapah dengan didukung dengan gestur senyuman. Menurut hasil wawancara penulis dengan sang mama, dapat diketahui bahwa sejak kecil Arkhan biasa diberikan apresiasi berupa pujian atau sorakan saat berhasil melakukan suatu hal. Melalui kejadian berulang ini maka sang anak terbiasa menunjukkan ungkapan kegembiraannya saat berhasil melakukan sesuatu dengan menunjukkan atau memamerkannya pada anggota keluarga guna mendapat apresiasi.

(4) Konteks: Suatu siang Arkhan (B) sedang bermain bersama temannya di kamar dengan ditemani oleh neneknya (A).

A: Uti, mamas Arkhan ga nakal dong. Main bersama-sama. (sambil memberi mainan ke temannya)

B: Iya kan pintar. Mainnya harus sama-sama.

Ungkapan kegembiraan pada data (4) ditunjukkan lewat pengonsepan yang ia terima. Biasanya saat Arkhan bermain dengan temannya akan berakhir dengan tangisan sebab berebut mainan. Setelahnya Arkhan akan disebut nakal oleh anggota keluarganya sebab tidak mau berbagi mainan. Namun, pada saat itu Arkhan mau berbagi mainannya sehingga ia merasa telah melakukan sebuah keberhasilan. Kegembiraan sebab keberhasilan tersebut diungkapkannya dengan memamerkan hal tersebut pada neneknya. Arkhan sudah mengenal makna kata ga atau tidak sehingga mengombinasikannya dengan kata nakal sebagai penolakan bahwa hari itu ia tidak melakukan perbuatan nakal seperti biasanya. Hal ini pula yang membuatnya menggunakan kata ga nakal dari pada kata baik atau pintar untuk menggambarkan perbuatannya.

(5) Konteks : Pada suatu malam Arkhan (B) bermain bola ditemani kakeknya di $\operatorname{kamar}(\mathrm{A})$.
A: Arkhan main apa?
B: Bola.

A: Sini tendang!

B: (menendang bola) Yeee! Gol! (sambil tertawa dan melompat)

Data (5) merupakan ungkapan kegembiraan yang terhasil dari pengamatan Arkhan terhadap lingkungan sekitar. Ayah dari Arkhan adalah penggemar sepak bola dan sering memainkan game sepak bola di gawainya. Saat sedang bermain dan mencetak gol, sang ayah biasanya akan berseru gol! secara reflek. Hal ini rupanya diperhatikan oleh Arkhan yang kemudian ia gunakan saat sedang bermain bola. Kegembiraan Arkhan saat menendang bola diungkapkannya lewat ujaran Yeee! Gol! meski ia tidak mengerti makna seutuhnya. Berdasarkan hasil pengamatannya, ia hanya memahami bahwa 
kegembiraan setelah menendang bola dapat disampaikan dengan ungkapan tersebut.

\section{Media Elektronik}

Zaman yang terus berkembang membuat segala hal berevolusi ke bentuk yang lebih canggih. Penggunaan gawai atau alat elektronik lain pada akhirnya terasa seperti sebuah keharusan. Anak-anak sejak lahir sudah diperkenalkan dengan berbagai macam alat elektronik seperti gawai, televisi, pengeras suara, dan lain sebagainya. Pada akhirnya alat elektronik tersebut akan memengaruhi manusia di berbagai macam aspek. Salah satu aspek yang mungkin terpengaruh adalah aspek bahasa.

Pemerolehan bahasa anak sangat mungkin terpengaruh sebab media elektronik sudah melingkupi seluruh lingkungan anak.

(6) Konteks: Suatu pagi Arkhan (B) sedang disuapi kue oleh neneknya (A).
A: Enak gak kuenya?
B: Enak sekali. Mamas Arkhan suka kue. Kue cubit uma meler hehehe. (lalu tertawa)

Data (6) menunjukkan ungkapan kegembiraan sebab makan kue yang disuka. Arkhan sejak lama suka menonton video kartun islami Nussa Rara di Youtube. Sebab telah menonton berulang kali maka ia hafal dengan beberapa dialog di dalamnya. Pada salah satu adegan di mana Rara menyantap kue buatan ibunya, ia mengekspresikan rasa sukanya lewat ungkapan Rara suka kue buatan uma. Kue cubit buatan uma meler. Dialog pada adegan tersebut dihafal oleh Arkhan yang kemudian mempraktikkannya untuk menunjukkan rasa gembiranya saat memakan kue yang disuka.

(7) Konteks: Suatu sore Arkhan (B) diajak bermain ke taman bermain anak-anak oleh ayahnya (A).
A: Mamas Arkhan main apa?
B: Main perosot-perosotan.

\section{A: Seru ya?}

B: Mamas Arkhan tepuk tangan. (Arkhan bertepuk tangan sambil tertawa dan melompat)

Data (5) berkaitan dengan kesukaan Arkhan terhadap musik. Menurut sang mama, Arkhan adalah anak dengan tipe audio maka tidak heran ia mudah menghafal lagu-lagu yang sering diputar sang mama di gawai untuk menghiburnya. Salah satu lagu ada yang berlirik kalau kau senang hati tepuk tangan. Biasanya Arkhan akan ikut bernyanyi sambil melakukan aktivitas yang disebutkan dalam lagu. Hal ini nampaknya dipahami Arkhan sebagai sebuah konsep bahwa tepuk tangan adalah ungkapan rasa bahagia. Oleh karena itu pada saat Arkhan merasa gembira sebab dapat bermain di taman, ia mengungkapkannya dengan menunjukkan lewat ungkapan tepuk tangan. 


\section{SIMPULAN}

Pemerolehan bahasa anak usia 2 tahun meliputi aspek fonologi dan sintaksis. Pada usia ini anak sudah mampu menghasilkan kalimat dengan relasi gramatikal dasar. Pemerolehan bahasa ditunjukkan dalam komunikasi sehari-hari anak. Anak usia dua tahun umumnya merasakan banyak emosi, salah satunya gembira. Pemerolehan bahasa juga dipakai anak dalam mengungkapkan kegembiraan dalam berkomunikasi.

Lingkungan bahasa memiliki peran penting dalam ungkapan kegembiraan anak. Ada dua lingkup lingkungan bahasa yang paling berpengaruh, yakni keluarga, dan media elektronik. Lewat keduanya anak meniru, mengamati, membiasakan diri, serta melakukan trial dan error dalam pemakaian hasil pemerolehan bahasa saat menyampaikan perasaan gembiranya.

\section{DAFTAR PUSTAKA}

Chaer, Abdul. (2009). Psikolinguistik: Kajian teoretik. Jakarta: PT Rineka Cipta.

Krashen, S. D. (1981). Second Language Acquisition and Second Language Learning In Teaching with Educational Technology in the 21st Century. Oxford: Pergamon Press Inc.

Nuryani \& Putra, (2013). Psikolinguistik. Tangerang Selatan: Mazhab Ciputat.

Purba, A. (2013). Peranan Lingkungan Bahasa Dalam Pemerolehan Bahasa Kedua. Jurnal Pena, 3(1), 13-25.
Pusat Penelitian Lingkungan Hidup Malang. (2009). Pendidikan Lingkungan Hidup (Vol. 1). Malang: Universitas Negeri Malang.

Riana, M. (2015). Emosi Anak Usia Dini dan Strategi Pengembangannya. Jakarta: Kencana.

Thoriqussu'ud, M. (2013). Pengantar psikolinguistik. Surabaya: UIN Sunan Ampel. 